\title{
국제사회의 언타이드 원조현황과 우리의 대응방안
}

권 율 / 국제개발협력팀장, 대외경제정책연구원(KIEP)

\section{1. 머리말}

우리나라는 국제사회에서 주목받고 있는 신흥 원 조공여국으로서 2010년을 목표로 OECD 개발원 조위원회(DAC) 가입을 추진하고 있다. 2007년 7 월 국제개발협력위원회에서 ' $\mathrm{OECD} / \mathrm{DAC}$ 가입로 드맵' 이 심의 · 확정됨에 따라 국제규범에 부합한 우리의 원조정책 및 제도 개선이 시급한 실정이다. 현재 $\mathrm{DAC}$ 가입 준비와 관련하여 무엇보다도 제도 적 보완이 필요한 부분은 2001년 채택된 최빈개도 국에 대한 언타이드화 권고라고 할 수 있다.

국제적으로 $\mathrm{MDG}$ 달성을 위한 원조의 질적 개선 과 효과성 제고를 위한 노력이 확대되면서 언타이 드 원조 추세가 강화되고 있고, DAC 회원국들의 경우 양자간 원조의 언타이드 비중을 2001년 $79.7 \%$ 에서 2006년 94.5\%로 크게 확대하였다. 특 히 2005년 3월 채택된 파리선언에서는 수원국의
현지 원조조달 시스템 활용을 권고하고 있는데, 언 타이드 원조는 조달비용을 낮추어 원조자금의 비 용대비 효과적 집행을 가능케 하고, 입찰을 통한 투명성 제고와 원조사업의 책임성 제고에 기여할 수 있다. 그러나 언타이드 원조를 확대하기 위해선 사업관리 및 운영에 있어서 제도 개선은 물론 우리 기업들의 사업개발 수행능력 및 국내 컨설턴트의 수주경쟁력을 강화하기 위한 합리적인 보완책이 전제되어야 하기 때문에 단계적이고 점진적인 접 근이 불가피하다.

따라서 본고는 언타이드 원조에 대한 국제적 이슈 와 흐름을 분석하고, 이를 토대로 무상원조사업을 중심으로 우리나라 $\mathrm{ODA}$ 의 언타이드화 추진전략 과 정책방향을 모색해 보고자 한다. 특히 $\mathrm{DAC}$ 의 최빈국 원조 언타이드 권고안을 중심으로 최근 언 타이드 원조에 대한 주요 쟁점과 이슈를 검토하고, 국제적 추세를 반영하여 ODA 조달시장 규모를 추 
정하고자 한다. 언타이드화로 예상되는 다양한 파 급효과를 감안하여 전략적인 추진로드맵과 주요 정책과제를 다각적으로 검토해 보고자 한다.

\section{2. 국제사회의 언타이드 원조현황}

\section{가. 언타이드 원조에 대한 주요 쟁점과 이슈}

일반적으로 수원국이 조달하는 수입물자 · 용역의 조달처를 공여국 또는 일부 소수국가로 한정하지 않는 경우를 언타이드(untied) 원조라고 한다." 따 라서 타이드(tied) 원조는 조달의 용도, 물자·용 역의 품목, 사양, 규격 등을 제한하거나 조달처가 되는 국가나 지역을 제한하는 것을 의미하는 것이 지만, 현재 원조관행상 타이드 원조와 언타이드 원 조의 범주를 명확하게 구분하기는 어렵다. ${ }^{2}$

이에 따라 $\mathrm{OECD}$ 개발원조위원회(DAC)는 구매적 격국의 적용범위를 제한함으로써 공여국의 수입유 발효과가 발생하는가에 초점을 맞추고 있고, 이러 한 측면에서 부분언타이드 원조도 타이드로 인식
하고 있다. 실제로 공여국 입장에서는 타이드 원조 를 통해 단기적으로 자국의 수출 및 고용증진을 도 모해 온 것이 사실이다.

개도국 진출을 위한 보조금의 성격을 지니는 타이 드 원조에 대한 규제는 $\mathrm{OECD}$ 차원에서 기본적으 로 무역 왜곡을 막는 방향으로 진행되어 왔고, 그 동안 수출신용과 연계된 양허성 수준에 대한 논란 이 지속되어 왔다. 1972 년 $\mathrm{DAC}$ 는 ODA의 조건으 로 $25 \%$ 의 증여율(Grant Element) 기준을 도입하 여 기회비용의 개념을 설정하였고, 1980 년대에 들 어서서 선진국이 자본재의 수출증대를 위해 조건 부 원조와 혼합신용흐를 확대함에 따라 $\mathrm{DAC}$ 는 1987년 '혼합신용과 타이드, 부분 언타이드 ODA 에 대한 지침' ${ }^{4)}$ 을 채택하였다. 즉, 타이드 원조공 여시 최빈국 지원에 대해서는 $50 \%$ 이상, 기타 개도 국 지원에 대해서는 $35 \%$ 이상의 양허성 수준(C. L.)을 유지하도록 하였다.5) 또한 $\mathrm{DAC}$ 와 $\mathrm{OECD}$ 의 무역위원회는 타이드 원조에 대한 공동 규제노력 으로 1992년 2월 소위 '헬싱키 패키지(Helsinki Package)라고 불리는 '공적수출신용 가이드라인 에 관한 협약 ${ }^{6)}$ 을 개정한 바 있다. 헬싱키 패키지 ${ }^{7}$

\footnotetext{
1) 언타이드 원조는 비구속성 원조 혹은 비연계성 원조라고도 하나, 본문에서는 언타이드 원조라는 용어를 사용함.

2) 구속적인 계약이나 협정상 문언이 없다하더라도 실질적으로 공여국 및 소수국가로 조달처가 제한되는 경우 사실상의 타이드(de facto tied) 또는 비공식 타이드(informal tied) 원조로 부르기도 함.

3) 혼합신용이란 유럽국가들이 차관형식의 금융지원 대신에 유무상원조자금과 기타 비원조성 또는 비양허성 자금을 결합하여 수원국의 상환부담상 혜택차 원에서 차관으로 지원하는 것과 동일한 효과가 나도록 지원하는 복합적인 금융지원방식임.

4) DAC Guiding Principles for Associated Financing and Tied and Partially Untied ODA.

5) 증여율이 일률적으로 $10 \%$ 의 할인율을 적용하는 것과는 달리 양허성 수준(C.L.)은 각 원조통화의 상업참고금리(CIRR)를 반영한 차등할인율을 적용하는 데, 일반적으로 5년 만기 국채수익율에 $100 \mathrm{bp}$ 를 가산한 금리로 결정됨.

6) Arrangement on Guideline for Officially Supported Export Credits.

7) 헬싱키 패키지의 규제대상은 ODA 차관과 혼합신용을 아우르는 조건부 원조신용(tied aid credit)으로서 양허성 차관이 공여국의 무역정책 도구로 활용되 고 시장을 왜곡할 가능성을 방지하기 위한 규제로서 EU 15 개 회원국, 호주, 뉴질랜드, 캐나다, 일본, 한국, 노르웨이, 스위스, 미국 등 23개국이 서명하였 다. 서명국은 조건부 혼합신용차관을 제공할 때 $\mathrm{OECD}$ 무역위원회 사무국을 통해 회원국에게 사업내용을 통보해야 하며 적합성을 평가받아야 된다(자세 한 내용은 권율, 2000 참고).
} 
는 일반상업 금융으로 지원이 가능한 수익성이 양 호한 사업에 대한 혼합신용에 대한 규제조치이기 때문에 2 백만 $\operatorname{SDR}(2.9 \text { 백만 달리 })^{8}$ 미만의 소규모 사업, 양허성 수준 80\%를 초과하는 준증여(near grants)와 순수증여(pure grants)의 경우와 최빈 개도국(LDC)에 대한 원조의 경우에는 적용되지 않았다.9) WTO 체제 출범 이후에는 공적 수출신 용에 있어서 보조금적 요소를 제거, 1997년 11월' 셰어러 패키지 '에 의해 협약이 개정된 바 있다. 우 리나라의 경우 1996년 $\mathrm{OECD}$ 에 가입하였기 때문 에 협약상의 매칭 통보 및 협의 등 지원의 투명성 을 목적으로 한 제규정에 따라야 하며, 협약에 부 과되지 않는 신용을 공여할 경우 그 내용을 밝혀야 하는 의무가 있다.

이미 언급한 바와 같이 국제적으로 소규모 사업, 양허성 수준 $80 \%$ 를 초과하는 경우와 최빈국 $(\mathrm{LDCS})$ 에 대한 원조의 경우에는 타이드 원조규제 가 적용되지 않았다. 그러나 $\mathrm{DAC}$ 는 1998년 4월
최빈국에 대한 원조의 언타이드화를 제안한 후 금 융작업반과의 협의 하에 2001 년 최빈국 원조 언타 이드 권고안을 도출하여 수출신용과 연계된 타이 드 원조 뿐만 아니라 최빈국에 대한 원조까지 언타 이드화의 적용범위를 크게 확대하고 있다. ${ }^{10}$

\section{나. DAC의 최빈국 원조 언타이드 권고안}

DAC가 2001년 최빈국에 대한 원조의 언타이드화 를 권고하게 된 직접적인 계기는 타이드 원조의 비 효율성을 개선하고, $\mathrm{MDG}$ 달성에 합목적적으로 접근하기 위해서이다. 2002년 1월부터 시행된 최 빈국에 대한 언타이드 원조의 적용대상은 〈표 1〉 에서 알 수 있듯이 국제수지 및 구조조정을 위한 예산지원, 채무탕감, 투자프로젝트(investment project) 등 총 8 개 분야이다. 그러나 식량원조, 기 술협력의 경우 특정 프로젝트 준비나 수행과 무관 한 독립된 기술협력(Free-standing Technical Assistance: FTC)은 제외되었다. 다만, 특정프로

〈표 1〉 최빈국에 대한 원조의 언타이드화 적용범위

\begin{tabular}{|c|c|}
\hline 시 한 & 2002. 1월시행 \\
\hline 적용대상사업 & $\begin{array}{l}\text { 국제수지 및 구조조정지원, 부채탕감, 부문 혹은 다부문 프로그램원조, 투자사업원조, 수입· 현물지원, } \\
\text { 상업서비스계약, 구매가 따르는 NGO에 대한 ODA, 투자관련 기술협력(RTC) }\end{array}$ \\
\hline 적용제외사업 & 독립적인 기술협력(FTC), 식량원조 \\
\hline 최소적용규모" & $\begin{array}{l}\text { - 일반사업 : 70만 SDR(약 1백만 달러)이상 } \\
\text { - IRTC : 13만 SDR(약 19만 달러)이상 }\end{array}$ \\
\hline
\end{tabular}

주: 1) 2001년 권고에서 제외되었던 최소규모적용 규정은 2006년 7월부터 언타이드 대상에 포함됨.

8) SDR(Special Drawing Rights)은 국제통화기금(IMF)의 국제통화인출권으로 1SDR은 1.58달러 수준임 9) 정창호(2005) 참조.

10) Recommendation on Untying Official Development Assistance to the Least Developed Countries. 
젝트의 투자지원을 위한 기술협력(Investment Related Technical Cooperation: IRTC)은 언타 이드 대상에 포함 되었다. ${ }^{11}$

한편, 국제적으로 $\mathrm{MDG}$ 달성을 위한 원조의 질적 개 선과 효과성 제고를 위한 노력이 확대되면서 2005년 2 월 채택된 파리선언ㄹㅇ에서는 수원국의 현지 원조조 달 시스템 활용 및 언타이드 원조 확대를 권고하는 주요 지표가 채택되었음에 주목할 필요가 있다.

파리선언은 중점추진과제로 5 개 원칙을 제시하고 (그림 1 참조), 그 성과를 측정하기 위한 12 개의 지 표를 설정하고 있다. 수원국의 개발전략에 공여국 원조의 일치(Alignment)에서 공여국은 수원국의 정부조달 시스템을 활용할 것을 권고하고 있다.

\section{〈그림 1〉 파리선언의 추진과제와 주요 지표}

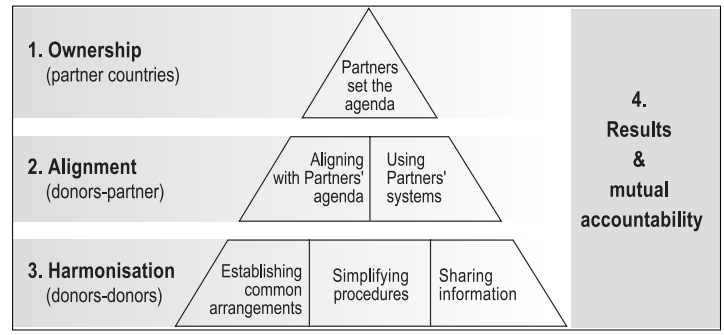

자료 : 권율외(2006), p. 49 재인용

파리선언에서 제시된 언타이드화 관련 지표는 다 음과 같다. 첫째, 수원국의 $1 / 3$ 이 4 단계로 구성된
정부조달 평가에서 최소한 한 단계 이상 상승(지표 $2 \mathrm{~b}){ }^{13)}$ 둘째, 모든 국가가 수원국 정부조달시스템 을 활용, 수원국의 정부조달시스템을 활용하지 않 는 공공부문 원조의 $2 / 3$ 감축(조달성과척도 $\mathrm{A}$, 지 표 $5 \mathrm{~b})$, 셋째, 공여국의 $90 \%$ 가 수원국 정부조달시 스템 활용, 수원국의 정부조달시스템을 활용하지 않는 공공 부문 원조의 $1 / 3$ 감축(조달성과척도 $\mathrm{B}$, 지표 $5 \mathrm{~b})$, 넷째, 원조의 언타이드화를 위해 양자간 원조의 언타이드 비율의 지속적 증대(지표 8)를 명 시하고 있다. ${ }^{14)}$

파리선언은 2010년까지 이행키로 합의되었을 뿐 만 아니라, 2008년 아크라에서 파리선언 중간평가 를 위한 고위급회담(HLF)이 개최될 예정이어서 원조의 언타이드화 문제는 지속적으로 국제사회의 관심이 될 전망이다.

\section{다. 언타이드 원조의 국제비교와 추진현황}

\section{1) 양자간 원조의 언타이드 비율}

양자간 원조의 언타이드 비율(기술협력과 행정비 용을 제외한 약정액 기준)은 DAC 평균으로 2001 년 79.9\%에서 2006년 94.5\%로 크게 증가하고 있 다. 영국은 2001년, 호주와 덴마크는 2006년 자국

\footnotetext{
11) IRTC에는 프로젝트의 타당성조사, 기본/상세설계(front end engineering and design: FEED), 건축엔지니어링(architect engineering:A\&E), 입찰절차를 자 문 관리하는 구매 관련 기술지원(Procurement-related technical assistance: PRTA) 등이 포함됨.

12) 파리에서 100 개국 이상의 국가가 모여 "원조 효과성 관련 고위급 포럼"(Paris High Level Forum on Aid Effectiveness)에서 '원조효과 제고를 위한 파리선 언'이 채택되었는데, 자세한 내용은 권율외(2006), p. 4852 참조.

13) 지표 2a인 공공재정관리(PFM: Public Financial Management) 시스템은 세계은행의 국가정책및제도평가(CPIA: Country Policy and Institutional Assessment)를 기준으로 평가됨. 그러나 지표 $2 \mathrm{~b}$ 인 조달체제 평가를 위한 정량적 기준은 아직 마련되지 않음.

14) 파리선언의 주요 지표 및 가이드라인에 대한 상세 내용은 $\mathrm{OECD(2007)} \mathrm{참조.}$
} 
원조의 언타이드화를 선언하였으며, 아일랜드는 2006년의 경우 그리스(39.1\%), 포르투갈(61.3\%), 2001년 이래로 지속적으로 $100 \%$ 언타이드 원조를 캐나다(62.9\%), 이탈리아(77.0\%), 스페인(82.8\%) 공여하고 있다.

등은 상대적으로 낮은 수준을 기록하고 있다.

〈표 2〉 DAC 주요국의 언타이드 비율"

\begin{tabular}{c|c|c|c|c|c|c|c|c}
\hline 국 가 & '79 ' 99 & '90 '99 & 2001 & 2002 & 2003 & 2004 & 2005 & 2006 \\
\hline DAC 전체 & 45.8 & 65.1 & 79.9 & 85.3 & 91.8 & 91.3 & 91.8 & 94.5 \\
\hline 호 주 & 54.1 & 45.9 & 59.3 & 56.7 & 67.2 & 77.1 & 71.9 & - \\
\hline 벨기에 & 32.6 & 26.0 & 89.8 & 92.6 & 99.1 & 92.7 & 95.7 & 90.7 \\
\hline 캐나다 & 27.5 & 40.9 & 31.7 & 61.4 & 52.6 & 56.7 & 59.4 & 62.9 \\
\hline 프랑스 & 44.0 & 48.1 & 66.6 & 91.5 & 93.1 & 94.2 & 94.7 & 95.6 \\
\hline 그리스 & - & 3.3 & 17.3 & 13.9 & 93.8 & 23.0 & 73.6 & 39.1 \\
\hline 일 본 & 60.8 & 88.2 & 81.8 & 82.8 & 96.1 & 94.4 & 89.6 & 95.6 \\
\hline 뉴질랜드 & 56.2 & 75.5 & - & 76.0 & 81.4 & 81.2 & 92.3 & 90.2 \\
\hline 스페인 & - & 5.3 & 68.9 & 59.9 & 55.8 & 67.7 & 86.6 & 82.8 \\
\hline 스웨덴 & 73.9 & 83.7 & 96.5 & 87.6 & 100.0 & 99.4 & 98.3 & 100.0 \\
\hline 한 국 & & 0.9 & 1.5 & 1.6 & 2.5 & 4.2 & 2.6 & - \\
\hline
\end{tabular}

주: 1) 기술협력과 행정비용을 제외한 약정액 기준

자료: OECD/DAC, $\mathrm{KOICA}$

〈그림 2〉 2006년 DAC 주요국의 언타이드 비율"

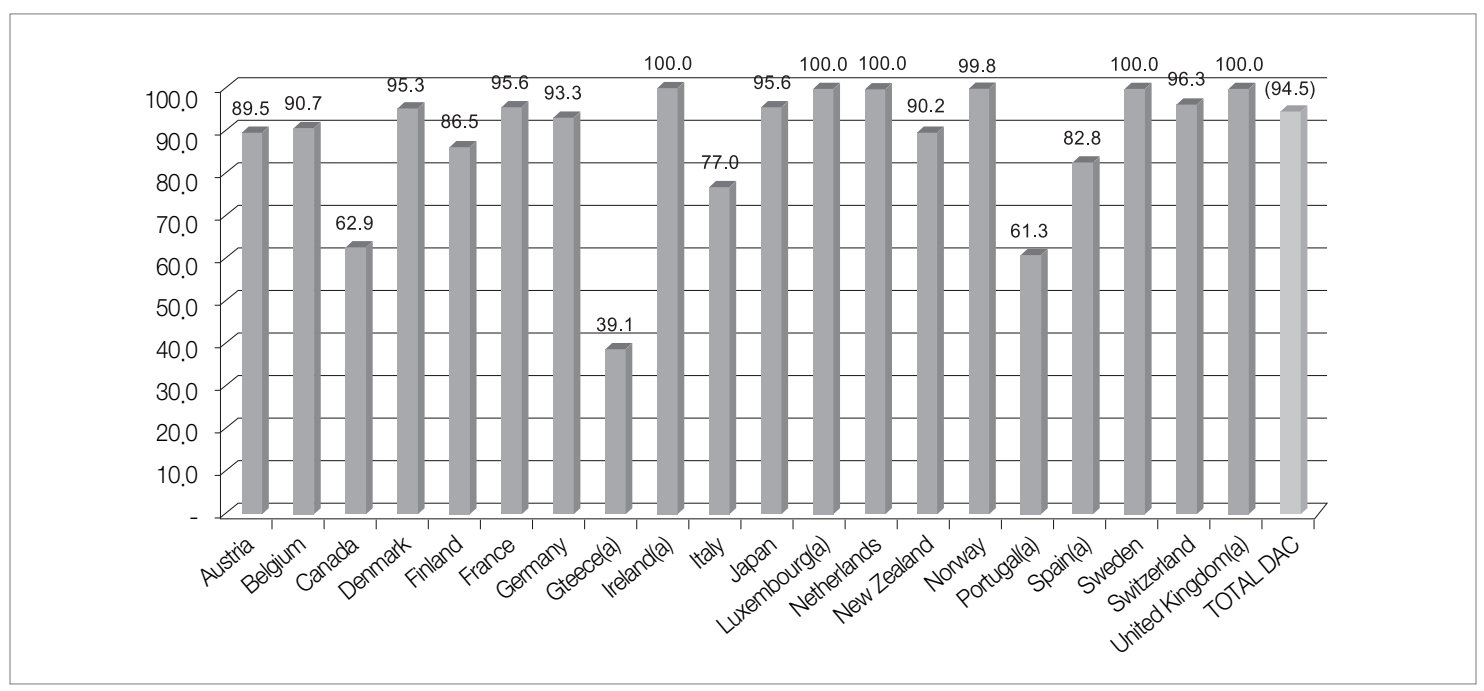

주: 1) 기술협력과 행정비용을 제외한 약정액 기준

2) 그리스, 아일랜드, 룩셈부르크, 포르투갈, 스페인, 영국은 집행액 기준 자료: $\mathrm{OECD} / \mathrm{DAC}$ 
최빈국에 대한 양자간 원조 규모는 1991 2001년 115 억 달러(연평균)에서 2005년 214억 달러로 크 게 증가하고, 최빈국에 대한 양자간 언타이드 원조 규모는 164 억 달러로 기록되었다. 이는 최빈국 언 타이드화에 대한 반작용으로 최빈국 원조규모 자 체가 양적으로 감소될 것이라는 당초의 우려를 불
최빈국 언타이드 원조 권고안은 $\mathrm{DAC}$ 회원국들의 노력이 서로 적절한 균형을 이루고, 향후 진전 상 황을 점검하기 위해 두 가지 지표를 사용하고 있 다. 첫째, 양자간 최빈국 $\mathrm{ODA}$ 의 언타이드 비율로 서 최빈국에 대한 양자 언타이드 비율의 DAC 기준 (reference point)은 0.6 이상이다. 둘째, 노력분담

〈표 3〉 DAC 주요국의 최빈국에 대한 양자 언타이드 비율

\begin{tabular}{|c|c|c|c|c|}
\hline \multirow{2}{*}{ 국 명 } & \multirow{2}{*}{$\begin{array}{c}1999 \text { } 2001 \\
\text { (연평균) }\end{array}$} & \multirow{2}{*}{2004} & \multicolumn{2}{|c|}{2005} \\
\hline & & & $\%$ & 백만 달러 \\
\hline 호 주 & 0.42 & 0.91 & 0.49 & 146 \\
\hline 오스트리아 & 0.34 & 0.68 & 0.83 & 104 \\
\hline 벨 기 에 & 0.49 & 0.99 & 0.99 & 507 \\
\hline 캐 나 다 & 0.40 & 0.76 & 0.66 & 466 \\
\hline 덴 마 크 & 0.77 & 0.80 & 0.94 & 771 \\
\hline 핀 란 드 & 0.69 & 1.00 & 0.95 & 193 \\
\hline 프 랑 스 & 0.54 & 0.85 & 0.83 & 1,270 \\
\hline 독 일 & 0.43 & 0.66 & 0.69 & 773 \\
\hline 그 리 스 & - & 0.41 & 0.25 & 6 \\
\hline 아일랜드 & 1.00 & 1.00 & 1.00 & 270 \\
\hline 이탈리아 & 0.30 & 0.80 & - & - \\
\hline 일 본 & 0.76 & 0.81 & 0.86 & 2,250 \\
\hline 룩셈부르크 & - & 1.00 & 0.98 & 79 \\
\hline 네덜란드 & 0.86 & 0.96 & 0.95 & 1,363 \\
\hline 뉴질랜드 & - & 0.36 & 0.30 & 23 \\
\hline 노르웨이 & 0.99 & 1.00 & 0.99 & 772 \\
\hline 포르투갈 & 0.42 & 0.99 & 0.70 & 144 \\
\hline 스 페 인 & 0.25 & 0.95 & 0.60 & 269 \\
\hline 스 웨 덴 & 0.69 & 0.98 & 1.00 & 691 \\
\hline 스 위 스 & 0.84 & 0.95 & 0.92 & 196 \\
\hline 영 국 & 0.63 & 1.00 & 1.00 & 3,035 \\
\hline 미 국 & 0.01 & 0.03 & 0.53 & 3,037 \\
\hline DAC 평균 & 0.55 & 0.68 & 0.76 & 16,367 \\
\hline
\end{tabular}

주: 최빈국에 대한 양자 언타이드 비율=Untied bilateral LDC ODA/total bilateral LDC ODA(약정액 기준)

자료 : $\mathrm{OECD} / \mathrm{DAC}(2007 \mathrm{a})$, p. 11 참조. 
〈표 4〉DAC 주요국의 최빈국에 대한 노력분담지수(ESCl)

\begin{tabular}{c|c|c|c}
\hline 국 명 & 1999 2001 (연평균) & 2004 & 2005 \\
\hline 호 주 & 0.05 & 0.05 & 0.04 \\
\hline 오스트리아 & 0.04 & 0.05 & 0.08 \\
\hline 벨 기 에 & 0.08 & 0.19 & 0.21 \\
\hline 캐 나 다 & 0.03 & 0.06 & 0.08 \\
\hline 덴 마 크 & 0.28 & 0.32 & 0.40 \\
\hline 핀 란 드 & 0.08 & 0.11 & 0.16 \\
\hline 프 랑 스 & 0.06 & 0.14 & 0.12 \\
\hline 독 일 & 0.04 & 0.07 & 0.06 \\
\hline 그 리 스 & - & 0.03 & 0.03 \\
\hline 아일랜드 & 0.16 & 0.20 & 0.21 \\
\hline 이탈리아 & 0.03 & 0.04 & - \\
\hline 일 본 & 0.05 & 0.05 & 0.07 \\
\hline 룩셈부르크 & - & 0.31 & 0.33 \\
\hline 네덜란드 & 0.22 & 0.22 & 0.31 \\
\hline 뉴질랜드 & - & 0.03 & 0.04 \\
\hline 노르웨이 & 0.30 & 0.34 & 0.40 \\
\hline 포르투갈 & 0.11 & 0.53 & 0.11 \\
\hline 스 페 인 & 0.02 & 0.04 & 0.06 \\
\hline 스 웨 덴 & 0.18 & 0.18 & 0.32 \\
\hline 스 위 스 & 0.09 & 0.11 & 0.09 \\
\hline 영 국 & 0.07 & 0.15 & 0.18 \\
\hline 미 국 & 0.01 & 0.01 & 0.03 \\
\hline DAC 평균 & 0.04 & 0.06 &
\end{tabular}

주: $\mathrm{ESCI}=($ 이국간 최빈국원조/GNP $\times$ 이국간 최빈국원조 언타이드비율 $)+$ 다자간 최빈국원조/GNP)

자료 : $\mathrm{OECD} / \mathrm{DAC}(2007 \mathrm{a})$, p. 11 참조.

지수(effort-sharing composite indicator: ESCI)원국 평균으로 55\%(1999 2001)에서 68\%(2004) 로서 양자간 최빈국원조의 언타이드 비율과 다자 로 증가하였고, 2005 년의 경우 $76 \%$ 를 기록하고 간 원조의 비율을 합한 지표를 사용하고 있다. ${ }^{15}$

2001년 '최빈국에 대한 ODA 언타이드화 권고안' 있다. 2005년 기준으로 아일랜드, 스웨덴, 영국은 최빈국 원조의 $100 \%$ 언타이드화를 달성하였다. 이 채택된 이후, 최빈국들에 대한 양자 언타이드 반면에 호주(49\%), 그리스(25\%), 뉴질랜드(30\%), $\mathrm{ODA}$ 비율은 지속적으로 증가하고 있다. $\mathrm{DAC}$ 회 하회하고 있다.

15) DAC는 다자간 최빈국 원조를 기본적으로 언타이드 원조로 규정하고 있는데, 이에 대해서는 DCD/DAC/FA/M(2002)2/PROV 참조. 
노력분담지수(ESCI)의 경우에도 1999-2001 기간 중 연평균 0.04에서 2004년 0.06, 2005년 0.08 로 지속적으로 증가하고 있다. $\mathrm{DAC}$ 는 기준치로 0.04를 권고하고 있으나, 2005년 DAC 전체 지수 는 0.08 로 권고 수준을 크게 상회하고 있다.

\section{3) $\mathrm{DAC}$ 의 최근 논의 동향}

최근 $\mathrm{DAC}$ 는 최빈국에 대한 언타이드 원조의 적용 대상 및 국가의 범위를 점차 확대시키는 추세라고 할 수 있다. 2001년 권고에서 제외되었던 소규모 원조(70만 SDR, 투자관련 기술협력 경우 13 만 $\mathrm{SDR}$ 도 언타이드 대상으로 포함키로 합의하여 2006년 7월 이후 발효된 바 있다. 양자간 원조 중 $1 / 3$ 을 차지하는 독립적 기술협력(FTC), 고채무 빈 곤국(Non $\mathrm{LDC} \mathrm{HIPC),} \mathrm{기타} \mathrm{저소득국(OLICs)} \mathrm{등}$ 으로 확대하는 방안도 적극적으로 검토하고 있다.

특히 언타이드 대상 국가를 확대하기 위하여 현재 Non-LDC HIPCs 국가로 범위를 확대 추진 중이 나, 2007년 9월 Non-LDC HIPCs에 대해 포르투 갈, 벨기에, 프랑스 등의 반대로 합의에는 실패하 였다. OLIC에 대해서는 일본의 반대로 인해 합의 도출이 어려운 실정이다. 한편 현재 $\mathrm{DAC}$ 권고안 의 언타이드 대상에서 제외되어 있는 독립적 기술 협력(FTC)과 식량원조(Food Aid)를 언타이드화 하고 있는 국가들도 $\mathrm{EU}$ 회원국 중심으로 확대되 고 있는 실정이다.
그러나 이러한 흐름이 $\mathrm{DAC}$ 차원에서 제도화되기 까지는 일정 정도 시간이 소요될 것으로 예상된 다. 독립적인 기술협력(FTC)의 경우 국가마다 상 이한 방법으로 추진되기 때문에 $\mathrm{DAC}$ 차원에서 FTC에 대한 재분류를 명확히 하기가 어렵고, 일 본, 프랑스 등이 반대하고 있어 합의를 도출하기 에 어려운 실정이다. 식량원조(Food Aid)의 경우 미국의 반대로 인해 당분간 포함되기 어려울 것으 로 전망된다.

\section{3. 국제조달시장 규모 추정}

최근 언타이드 원조가 확대됨에 따라 국제조달시 장 규모도 지속적으로 늘어나고 있다. 국제적으로 $\mathrm{ODA}$ 조달시장 규모는 명확히 산출하기 어렵지만, 전체 원조규모에서 사실상 타이드 되어 있거나 언 타이드로 분류되어 있더라도 구매 적격국이 자국 에 한정되어 있는 기술협력, 식량원조, 채무탕감, 행정비용 등을 제외한 규모로 추산해 볼 수 있다. 2006년의 경우 총 ODA 규모가 1,044 억 달러이 나, 사실상 조달시장에서 제외되는 자금내역을 제 외하면, 약 516 억 달러를 실질적인 ODA 조달시장 이라고 볼 수 있다.

연도별로 국제 ODA 조달시장 비중 변화를 산출해 보면, 1990년대 초반 $61.7 \%$ 에서 2004년 54.4\%, 2006년 49.4\%로 단계적으로 낮아지고 있음을 알 수 있다. 이는 그동안 원조규모가 급증하고 있음에 
〈표 5〉 2010년 국제 ODA 조달시장 규모 및 전망

(단위: 백만 달러, \%)

\begin{tabular}{c|c|c|c|c|c|c}
\hline \hline & 2002 & 2003 & 2004 & 2005 & 2006 & 2010 \\
\hline \hline 공적개발원조(ODA) & 58,297 & 69,065 & 79,432 & 107,099 & 104,421 & $132,361^{1)}$ \\
\hline 조달시장비중(\%) & 53.9 & 48.2 & 54.4 & 46.0 & 49.4 & $50.4^{2)}$ \\
\hline 조달시장규모 & 31,396 & 33,294 & 43,232 & 49,234 & 51,612 & 66,710 \\
\hline
\end{tabular}

주: 1) 2010년 ODA 규모는 DAC 추정치(OECD/DAC, 2007c 참조)

2) 2002-2006년 연평균, 총 원조규모에서 기술협력, 식량원조, 인도적 원조, 채무탕감, 행정비용 등을 제외한 규모로 추산

도 불구하고, 타이드 원조대상에서 제외되고 있는 채무탕감, 인도적 원조 등의 규모가 상대적으로 늘 어났기 때문이다. 예를 들어 기술협력의 경우 대략 $20 \%$ 수준을 유지하고 있지만, 최근 채무탕감 비율 이 전체 ODA에서 차지하는 비중이 2000년대 초 반 $10 \%$ 이하였던 것이 2006 년에는 $17.8 \%$ 까지 증 대하였다.

$\mathrm{DAC}$ 의 추정에 의하면, ${ }^{16)}$ 2010년 ODA 규모는 1,324 억 달러(GNI 대비 0.35\%)에 달할 것으로 예 상되고 있고, 2002년에서 2006년까지의 총 ODA 에서 차지하는 조달시장 비율(연평균) $50.4 \%$ 를 적 용할 경우 2010년 국제 ODA 조달시장 규모는 667 억 달러로 확대될 전망이다(표 5 참조). 이중 양자간 원조가 차지하는 비중이 $70 \%$ 수준임을 고 려할 때 양자간 조달시장 규모는 467억 달러에 달 한다.

$\mathrm{DAC}$ 의 계약 수주 보고시스템에 따르면, 금액기준 으로 공여국 기업의 수주율(2005년)이 $60.7 \%$ 로 가장 높고, $\mathrm{OECD}$ 회원국이지만 $\mathrm{DAC}$ 에 가입하지
않은 나라들의 수주율은 $17.7 \%$, 개도국 $6 \%$, 최빈 국 $15.6 \%$ 인 것으로 나타났다(그림 3 참조).

〈그림 3〉 DAC 주요 회원국의 언타이드 원조계약 수주율

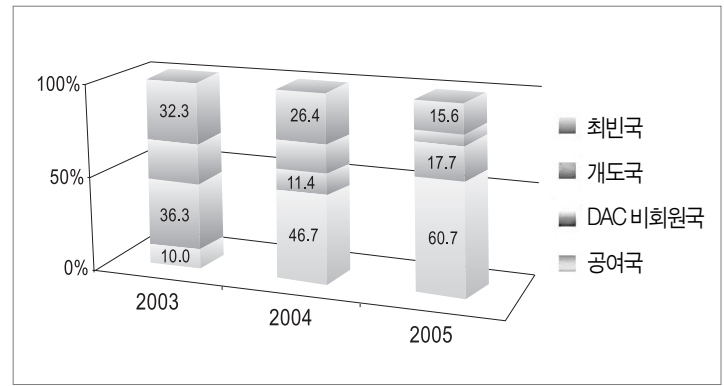

자료 : OECD/DAC(2007a), p. 11 참조.

최빈국에 대한 언타이드화가 권고된 이후 공여국 기업의 수주율은 2003 년의 경우 금액기준 $10 \%$, 건수기준 $27.1 \%$ 에 달했지만, 2005 년에는 금액 $60.7 \%$, 건수 $60.3 \%$ 를 기록하였다. 이는 언타이드 화에 따라 자국기업의 수주율이 크게 높아지고 있 음을 반영하는 것이고, 원조조달시장 확대에도 불 구하고, 수주계약에 있어서는 시장접근이 어려워 지고 있음을 시사하는 것이다.

특히 우리나라와 같이 $\mathrm{OECD}$ 회원국이면서 $\mathrm{DAC}$ 에

16) OECD/DAC(2007), Final ODA Flows in 2006, DAC Senior Level Meeting Room Document 2, p. 12. 
가입하지 않은 나라의 계약수주는 DAC 회원국들 의 자국기업 수주율이 높아지면서 크게 낮아지고 있다. 2003 년의 경우 금액기준 $36.3 \%$, 건수기준 $34.6 \%$ 에 달하던 수주율은 2005년 금액기준 $17.7 \%$, 건수기준 $10.8 \%$ 로 크게 낮아졌다.

따라서 우리나라를 포함한 DAC 비회원국(기타공 여국 포함)이 국제 $\mathrm{ODA}$ 시장에 접근할 수 있는 비 율은 2006년 수주율이 $17.7 \%$ 이므로 우리가 접근 할 수 있는 조달시장 규모는 대략 87.7억 달러 규 모라고 추정할 수 있다. 2010년의 경우에는 118억 달러 규모로 크게 증가할 것으로 보이나, 우리나 라의 계약 가능한 실제수주율은 DAC 비회원국과 기타 공여국 10 여개국중 조달시장에서 차지하는 경쟁력에 따라 크게 달라질 수 있을 것이다.

\section{4. 우리나라 무상원조의 언타이드화 추진방안}

\section{가. 언타이드 원조정책의 필요성}

2010년 DAC 가입을 준비하고 있는 우리나라로서 는 국제사회가 요구하고 있는 ODA 언타이드 기준 과 정책권고를 시행함으로써 국제사회에서 우리 $\mathrm{ODA}$ 의 위상 강화에 기여할 수 있다. 이미 언급한 바와 같이 DAC는 2001년 최빈국 언타이드화 권고
와 함께 2005년 파리선언에서 2010년까지 달성해 야 할 목표로 수원국 조달시스템 활용과 개선을 통 한 언타이드화를 권고하고 있기 때문이다. 특히 우 리나라의 경우 파리선언 서명국으로서 2008년 아 크라에서 개최되는 고위급포럼(HLF)과 파리선언 중간평가에 대비해야 한다.

또한 언타이드화를 통한 $\mathrm{ODA}$ 의 질적 수준 제고는 원조정책의 선진적 운용을 위해서 필수적이고, 우 리나라의 경우 국제적 수준에 비해 $\mathrm{ODA}$ 의 무상원 조 비율이 낮기 때문에 전략적으로 $\mathrm{ODA}$ 의 질적 수준 제고를 위한 언타이드 정책 추진에 보다 중점 을 둘 필요가 있다. 최근 국제개발협력 추세는 $\mathrm{MDG}$ 달성을 위한 원조의 양적 규모 확대뿐만 아 니라 질적 수준제고를 위한 지속적인 노력을 기울 이고 있다. 타이드 원조가 지속될 경우 수원국의 빈곤퇴치보다는 공여국의 경제적 이익을 고려한다 는 국제적 비난을 모면하기 어려우므로 언타이드 화에 대한 적극적인 노력이 필요한 실정이다.

우리나라 양자간 타이드 원조비율은 2001년 $94.5 \%$ 에서 2005 년 $81.4 \%$ 수준까지 지속적인 감 소세를 보이고 있으나, DAC 회원국 평균(2005) $6.5 \%$ 와 비교해볼 때 국제적 수준과는 큰 격차를 보이고 있다. 우리나라 언타이드 원조규모는 2005년 기준으로 양자간 원조의 $2.6 \%$ 로서 양적 규모로는 1,110 만 달러에 불과한 실정이다.

17) DAC에 가입하지 않은 OECD 회원국으로서 주요 원조공여국은 체코, 헝가리, 아이슬랜드, 한국, 폴란드, 슬로바키아 등이 있고, 중동국가중 쿠웨이트, 사 우디아라비아, 아랍에미레이트, 기타 원조공여국으로 대만, 이스라엘 등이 있음. 
〈표 6〉 우리나라 양자간 원조의 타이드화 현황

(단위: \%)

\begin{tabular}{c|c|c|c|c}
\hline 연 도 & 언타이드 & 부분 언타이드 & 타 이 드 & 양자원조(백만 달러) \\
\hline 2000 & 0.8 & 1.8 & 97.3 & 229.39 \\
\hline 2001 & 1.5 & 4.2 & 94.5 & 144.79 \\
\hline 2002 & 1.6 & 8.9 & 89.5 & 214.46 \\
\hline 2003 & 2.5 & 16.9 & 80.5 & 266.62 \\
\hline 2004 & 4.2 & 15.0 & 80.8 & 410.08 \\
\hline 2005 & 2.6 & 16.0 & 81.4 & 555.34 \\
\hline DAC 평균 (2005) & 91.8 & 1.82 & 6.5 & - \\
\hline
\end{tabular}

자료: $\mathrm{OECD} / \mathrm{DAC}$ Statistics Dataset 참조.

따라서 우리정부의 ODA 규모 확대 노력과 병행하

여 언타이드화를 통한 조달정책 개선이 시급하고, 이를 통해 개도국의 빈곤퇴치 및 개발수요에 실질 적으로 부응할 수 있도록 $\mathrm{ODA}$ 의 질적 수준을 제 고해 나가야 한다. 특히 언타이드 원조는 $\mathrm{ODA}$ 의 비용대비 효과성(cost effectiveness)을 제고하는 데 크게 기여하는 것으로 알려지고 있다. 일반적으 로 원조사업 입찰시 공여국 기업으로 제한될 경우 자국 기업에게 유리한 방식으로 추진하여 높은 비 용이 유발되는데, $\mathrm{DAC}$ 는 타이드 원조로 구매되는 재화와 용역의 가격이 국제경쟁가격에 비해 15 30\% 정도 높다고 보고하고 있다. ${ }^{18)}$ 식량원조 의 경우 현금지급으로 인접지역에서 조달되지 않 을 경우 수송비용이 높아 40 50\% 비용이 상승된 다. 세계은행은 언타이드 원조를 통해 $25 \%$ 의 비용 절감이 가능하다고 추정하고 있고, Action Aid는 언타이드 원조가 시장경쟁으로 원조조달비용을 $20 \%$ 저하시킨다고 주장하고 있다. ${ }^{19)}$
중장기적으로 언타이드 원조는 현지조달체제를 활 용하여 수원국의 주도적 역할과 사업집행의 신속성 을 제고하고, 수원국의 개발전략과 공여국의 원조 정책을 일치시키는데 기여하게 된다. 수원국 입장 에서 타이드 원조는 독자적인 투자계획을 어렵게 만드나, 언타이드 원조는 수원국의 개발전략과 중 장기적인 이익에 부합되는 기술선택의 기회를 확대 할 수 있는 이점이 있다. 즉, 수원국 주도의 투자계 획과 자금집행의 최적화를 강화하고, 개발도상국의 기업이 원조사업에 참여할 수 있는 기회를 제공함 으로써 원조의 효과성을 제고할 수 있게 한다.

따라서 언타이드 원조는 수원국 측의 개발목표 달 성에 적합한 재화 및 용역의 효율적 구매가 가능하 고, 공여국에게도 원조자금의 효율적 집행이 가능 토록 해준다. 타이드 원조가 정치적으로 국내적 지 지를 확보하기에 용이하다는 측면이 있는 것은 사 실이나, 타이드 원조는 경쟁을 제한함으로써 투명 
성이 떨어지고 부패의 가능성을 높이게 된다. 또한 언타이드 원조가 공여국과 수원국의 상호 작용을 저해한다는 일부 주장이 있으나, 상호작용은 정책 과 사업 선정 단계에서도 충분히 반영될 수 있다. 오히려 국민들은 원조효과성에 대해 더 관심을 가 지고 있고, 언타이드화를 통해 투명성과 책임성을 제고함으로써 $\mathrm{ODA}$ 에 대한 국민적 지지를 강화하 는 것이 보다 바람직하다고 할 수 있다.

그러나 언타이드화를 추진하려면 국제경쟁입찰이 나, 현지조달시스템을 이용해야 하기 때문에 ODA 조달시장에서 수주기회 축소, 사업관리상의 리스 크 요인 증대 등에 대처할 수 있는 합리적 보완책 이 마련되어야 한다. 언타이드 원조 확대로 국제적 인 ODA 조달시장 규모가 확대되고 있어 우리 기 업들의 시장진출 기회가 확대되고 있지만, 실질적 인 수주율 확대를 위해서는 국내 엔지니어링 산업 과 개발컨설턴트의 경쟁력이 뒷받침 되어야 한다. 하지만, 기술협력사업 비중이 낮은 우리나라 원조 체제의 구조적 취약성과 국내 컨설턴트 및 엔지니 어링 산업의 낮은 경쟁력은 오히려 언타이드 정책 추진의 부담요인으로 작용할 수도 있다. 따라서 $\mathrm{ODA}$ 의 언타이드화로 예상되는 다양한 파급효과 를 감안하여 단계적이고, 점진적인 도입방안을 검 토하는 것이 불가피한 실정이다.

\section{나. KOICA의 언타이드 추진방안}

$\mathrm{ODA}$ 의 언타이드화는 그 자체가 목적이 아니라 언
타이드 원조를 통해 원조효과성을 증대시키고자 하는 것이므로 우리나라 사정에 맞게 점진적으로 언타이드화를 추진하는 것이 중요하다. 공개적이 고, 경쟁적인 조달을 통해 원조사업의 목적을 가장 잘 달성할 수 있는 공급자를 선택함으로써 사업의 성공적 수행과 원조효과성 증대에 기여하기 위해 서는 $\mathrm{KOICA}$ 의 관련 제도 개선과 수행능력 제고에 일정기간이 소요되어야 하고, 언타이드 원조정책 의 점진적 도입방안을 위한 전략적 로드맵이 마련 되어야 한다.

$\mathrm{DAC}$ 는 언타이드화를 위해서 국제경쟁입찰 또는 수원국의 조달시스템을 활용할 것을 권고하고 있 으나, 리스크 관리, 모니터링, 사업자 검증 등에 대 한 철저한 준비가 필요함을 강조하고 있다. 이를 위해서는 원조사업 수행체제 전반에 대한 개선과 사전 준비가 필요하고, 조달관련 법규 보완 등이 전제되어야 하므로 점진적이고 단계적인 추진이 바람직하다.

이를 위해 우선 언타이드 적용 대상국가는 최빈국 $\rightarrow$ 고채무빈곤국(Non-LDC HIPC) $\rightarrow$ 저소득국 (OLIC)으로 단계적으로 확대하는 방안을 고려해 볼 수 있다. 국제적으로 언타이드화 추세가 강화되 고, $\mathrm{DAC}$ 의 최빈국에 대한 언타이드 권고가 2002 년 발효되면서 적용범위 및 대상국가를 확대하자 는 논의가 진행되고 있으나, DAC 회원국의 입장 이 달라 $\mathrm{DAC}$ 차원에서 제도화되기 까지는 일정정 도 시간이 소요될 것으로 예상된다. 따라서 우리나 
라의 경우 언타이드화 적용대상국을 최빈국으로 초점을 맞추되, 단계적으로 고채무빈곤국(Non$\mathrm{LDC} \mathrm{HIPC)과} \mathrm{저소득국(OLIC)으로} \mathrm{확대해} \mathrm{나가}$ 는 방안을 고려하는 것이 타당하다.

또한 언타이드 적용 대상사업에 있어서도 물자지 원사업 $\rightarrow$ 프로젝트사업 $\rightarrow$ 투자관련 기술협력 (IRTC) $\rightarrow$ 독립적인 기술협력(TC)으로 단계적으 로 확대하는 방안을 면밀히 검토해야 할 것이다. ${ }^{20}$ 즉, 물자지원사업의 언타이드를 우선적으로 추진 하되 프로젝트 사업의 경우에는 건축, 기자재, 건 축용역을 현지조달 연부를 고려하여 단계적으로 언타드화를 추진하는 것이 바람직하다. 투자관련 기술협력(IRTC)의 경우 사업성격상 현지 조달이 어려운 측면이 존재하므로 언타이드 대상 유무는 별도로 검토되어야 할 것이다.

또한 사업규모에 따른 입찰절차 개선도 필요하다. 소규모 사업의 현지구매의 경우 현지입찰을 원칙 으로 하되, 사업특성 및 현지조달시스템의 건전성 여부를 판단하여 언타이드 비율을 제고해 나가야 할 것이다. ${ }^{21)}$ 국제경쟁입찰의 경우 상대적으로 상 당 시일이 소요되고, 사업추진이 지체될 가능성이 높으므로 비용효과성이 낮은 소규모 프로젝트의 경우에는 가능한 수원국 조달시스템을 활용하는 것이 바람직하다. 물품 및 기자재 조달의 경우 조 달대행기관(procurement agent)을 DAC 가입 이 전에 지정하는 방안도 검토해 볼 필요가 있다. 영 국의 경우 3 개의 조달 대행기관을 통해 구매를 대 행하고 있으며, 조달대행기관은 중점지원국에 사 무소를 두고 DFID 혹은 수원국 정부를 대표하여 활동하고 있고, 일본, 덴마크 등도 이러한 조달대 행기관을 적극 활용하고 있다. 따라서 외교부와 $\mathrm{KOICA}$ 는 앞으로 조달업무를 관리 - 감독하는데 치중하고, 전문적인 조달대행기관을 통해 조달관 련 업무의 효율성과 투명성을 확보하는데 역점을 두어야 할 것이다.

이러한 제반 조치를 시행하기 위해서는 대내외적 여건을 고려하여 크게 3 단계로 나누어 추진로드맵 을 상정해 볼 수 있다. 우선 준비단계는 DAC 가입 을 목표로 언타이드 시범사업을 실시하되 최빈국 위주로 물자지원사업과 현지입찰로 진행중인 투자 프로젝트 내 건축계약을 주요 대상으로 선별적으 로 언타이드 사업을 확대해 나가는 것이다.

그리고 DAC 가입년도인 2010년을 목표로 무상원 조 언타이드율을 $50 \%$ 수준으로 확대하여 최빈국 에 대한 언타이드 원조를 중점적으로 추진하고, 저 소득국 일부에 시범적 사업을 추진하는 것이 바람 직하다. 이를 위해서는 국제입찰 및 수원국 현지 조달을 병행하고, 원조조달 시스템 개선을 통한 조

20) KOICA 언타이드 적용대상 사업비중(2006년 결산기준)은 물자지원(21.2\%), 프로젝트(32.6\%), 개발조사 중 종합계획 및 기초 · 실시설계(3.7\%), NGO 지원(1.5\%)로 KOICA 사업중 총 $59 \%$ (금액 기준)가 언타이드 적용대상임.

21) 소규모 사업기준은 DAC는 소규모 사업의 기준을 SDR 700,000 미만(약 10억 원) 일반원조사업 및 SDR 130,000(약 1.8 억 원) 미만 투자관련 기술협력사 업으로 설정 
〈표 7〉 연도별 무상원조 언타이드화 목표율

\begin{tabular}{c|c|c|c}
\hline \hline 연 도 & 국제사회 동향 & \multicolumn{1}{|c}{ 단 계 구 분 } & 목표언타이드율 \\
\hline 2008 & $\begin{array}{c}\text { 파리선언 중간점검 } \\
\text { (아크라 HLF) }\end{array}$ & $\begin{array}{l}\text { - 준비 및 시범단계 } \\
\text { (최빈국 대상 시범사업 실시) }\end{array}$ & $30 \%$ \\
\hline 2010 & DAC 가입 & $\begin{array}{l}\text { - 도입단계 } \\
\text { (최빈국 언타드화 추진 및 일부 저소득국 선별적으로 확대) }\end{array}$ & $50 \%$ \\
\hline 2015 & $M D G$ 목표연도 & $\begin{array}{l}\text { - 활성화 단계 } \\
\text { (전면적 언타이드 원조 추진) }\end{array}$ & $90 \%$ \\
\hline
\end{tabular}

달절차의 국제화가 필수적이다. $\mathrm{DAC}$ 는 원조사업 의 비용절감 및 효과성 제고를 위해 현지입찰을 권 고하고 있으므로 최빈국 지원사업에 대해서는 2010년까지 현지입찰을 원칙적으로 추진하고, 최 빈국 이외의 수원국에 대해서는 현지입찰을 2015 년 이전까지 단계적으로 확대해 나가야 할 것이다.

마지막으로 국제사회의 $\mathrm{MDG}$ 실현 목표연도인 2015년에는 언타이드율을 DAC 평균인 90\%까지 확대한다는 방침 하에 모든 국가와 사업을 대상으 로 언타이드 사업을 확대 실시한다는 로드맵을 통 해 국제사회의 일원으로서 역할과 책임을 실현할 수 있는 지속적인 정책적 노력이 필요하다.

\section{5. 정책과제}

언타이드 원조 확대를 위해서는 우리나라 원조조 달규정의 수정 및 보완이 필요하다. 언타이드 대상 사업 추진과 관련하여 입찰기준을 현지입찰 혹은 국제입찰기준으로 조정하고, 언타이드 대상사업의
예외 및 세부기준은 가능한 단순하고 명료하게 설 정함으로써 행정비용을 최소화해야 한다.

현지입찰의 경우 수원국 조달체제 활용을 위한 실 무적 검토가 이루어져야 하고, 중장기적으로 기술 협력을 통한 수원국 조달체제 역량 강화 방안이 마 련되어야 한다. 또한 현지입찰 수행시 절차 및 추 진방법을 사전에 수원국과의 협의를 통해 가능한 범위내에서 조달과정에 수원기관 등의 참여가 확 대 가능하는지 사전 검토가 필요하다. 특히 수원기 관과의 협의를 통해 가능한 시장 조사, 가격 조사 등 조달 과정에 수원국 참여를 제고하는 방안이 마 련되어야 한다.

또한 2005년 DAC 사무국으로 보고된 언타이드 계약 결과 중 $60 \%$ 가 공여국에 의해 조달되어 사실 상 타이드 원조(de facto tied aid)가 만연하고 있 음을 시사하고 있다. 이에 대응하여 ODA 사업발 굴 및 수주활동 지원을 위한 입찰정보 제공에 중점 을 두되, 중장기적으로 국내 컨설턴트의 경쟁력 및 역량 강화를 위해 개발조사사업을 확대하고, 정책 
컨설팅이 강화되어야 할 것이다. 이를 위해서는 사 전 타당성조사는 물론 정책지원형 컨설팅 및 개발 경험 전수, 부문 조사, 긴급개발조사를 도입하여 국내 엔지니어링 산업 및 컨설팅 능력을 획기적으 로 개선해야 한다. 국제적으로 실질적 타이드 관행 이 존재하는 동안 DAC의 본래 취지인 수원국 내 조달을 위한 현지입찰을 강화하되 우리 기업들의 현지입찰 참여를 확대할 수 있는 방안으로서 개발 조사사업을 통한 정책컨설팅은 보다 강화되어야 할 것이다. 이를 위해 수원국의 경제 - 사회 발전에 기여할 수 있는 각종 개발 사업 및 계획수립을 적 극 지원하고, 주요 기초조사, 종합개발계획, 타당 성 조사 등을 활성화함으로써 정책적 파급효과를 극대화할 필요가 있다.

한편 언타이드 원조 확대로 점차 현지기업, 외국 개발컨설턴트 등의 수주비율이 높아질 것이므로
제반 사업추진의 모니터링 및 평가체제를 강화해 야 한다. 국제경쟁입찰(ICB)의 위험관리, 모니터 링, 사업자에 대한 검증 등이 중요하므로 이에 대 한 철저한 준비가 필요하다. 특히 공여국에 의한 직접 현지 조달을 실시할 경우, 부패방지를 위한 제반조치와 모니터링이 매우 중요하고, 제반 협력 사업의 사후관리체제도 보강되어야 할 것이다.

특히 2010년 DAC 가입이전 조달대행기관 지정을 통해 조달절차의 개선 및 투명성을 제고하여 모니 터링 체제를 획기적으로 개선할 필요가 있다. 일본 및 영국에서 조달전문기관을 통해 ICB 실시하고 있는 바, 이에 대한 세부 조사를 통해 모니터링 및 조달절차 개선방안이 마련되어야 할 것이다. 현지 업체의 사업수행 능력(기술, 자본 등) 평가 기준을 마련하여 부패 방지 및 사업 추진의 효과성이 제고 되도록 적극적인 정책적 노력이 필요하다. 


\section{[ 참고 문헌 ]}

권 율 1999.『OECD/DAC의 공적개발원조 논의와 방향』. 대외경제정책연구원.

2000. `공적자금의 연계를 통한 對개도국 경제협력추진방안』, 이창재 · 안응호 공저. 대외경제 정책연구원.

2003. 우리나라 ODA의 통계작성 및 추계방식의 개선방안』. 국회통일외교통상위원회 용역 보고서.

권 율 외. 2002. `UN 개발재원 국제회의의 주요 내용과 평가」. "KIEP 세계경제」, 제5권 제4호. 대 외경제정책연구원.

2005. 개발조사사업 확대발전방안 - 한국국제협력단.

2006. 우리나라 대외원조정책의 선진화방안 - 대외경제정책연구원, 서울, 2006. 12. 정창호. 2005. 「OECD 타이드 원조 규제가 우리나라 ODA에 미치는 영향」, 대외경제전문가풀 ODA 연구회 발표 자료, 대외경제정책연구원, 2005.

ActionAid. 2002. Making a Case for Untying European Aid.

2004. Towards Effective Partnership, Untying Aid.

2005. Real Aid, An Agenda for Making Aid Work

DFID. 2005. The Blue Book, Essential Guilde to Rules \& Tools 2005.

Ministry of Foreign Affairs of Denmark. Danida. 2007. Danida Procurement

Guidelines - for Award of Service contracts according to the EU-Directive

OECD. 2007. 2006 Survey on Monitoring the Paris Declaration: Overview of the Results.

OECD/DAC. 1986. Good procurement Practices for Official Development Assistance.

2006. Implementing the 2001 DAC Recommendation on Untying ODA to the Least Developed Countries: 2006 Progress Report to HLM.

2007a. Implementing the 2001 DAC Recommendation on Untying ODA to the Least Developed Countries: 2007 Progress Report to HLM.

2007b. Final ODA Flows in 2006. DAC Senior Level Meeting Room Document 2. Oxfam International. 2005. "Food aid or hidden dumping? Separating wheat from chaff." Oxfam Briefing Paper. 